\title{
Vaccine institute treads out a wary path
}

[SEOUL] The world's first institution devoted to the research and development of vaccines for developing countries was formally established last week in Seoul, South Korea, when the United Nations Development Programme (UNDP) handed over governance of the nascent International Vaccine Institute (IVI) to an independent board of trustees composed of eminent scientists and health officials.

But the new institute, which will be built in a science park on the campus of Seoul National University and is currently in temporary offices at the university, faces a difficult future as it defines a role for itself in the complex political arena of world health care.

The institute was proposed by the UNDP in 1992. It comes under the umbrella of the Children's Vaccine Initiative, a broad coalition of organizations from public, nongovernment and private sectors with a secretariat at the World Health Organization (WHO) in Geneva that seeks to protect the world's children against infectious diseases.

The Asian institute is the brainchild of Seung-il Shin, an American of Korean descent. Shin played a key role in the late 1980s in introducing affordable hepatitis-B vaccines to the developing world, and felt the rapidly developing economies of Asia could provide a new source of funds and a means for developing affordable vaccines for the developing world.

Seoul was chosen to host the IVI in 1994 after bids from several Asian countries ended in a three-way run-off between South Korea, China and Thailand. But the international agreement to establish the institute took effect only in May, after three signatory countries ratified the agreement.

\section{Opposition}

The institute also had to overcome initial opposition from WHO, which saw it as impinging on its own Western Pacific Regional Office in Manila in the Philippines. Some US vaccine manufacturers were also apparently concerned that it might become a commercial competitor.

WHO's opposition abated after three of its officials were appointed to the 16-member board of trustees, including the head of the Western Pacific Regional Office. And one of the new board's first actions last week was to pass an amendment to IVI's constitution explicitly stating that it will not engage in the sale of vaccines, although it may prepare test vaccine lots for evaluation and clinical trials.

Over the next three years, while IVI's facilities are being built, the institute's staff, working with other Asian research centres and with financial backing from the Korean government, UNDP and private vaccine manufacturers, will concentrate on epi-

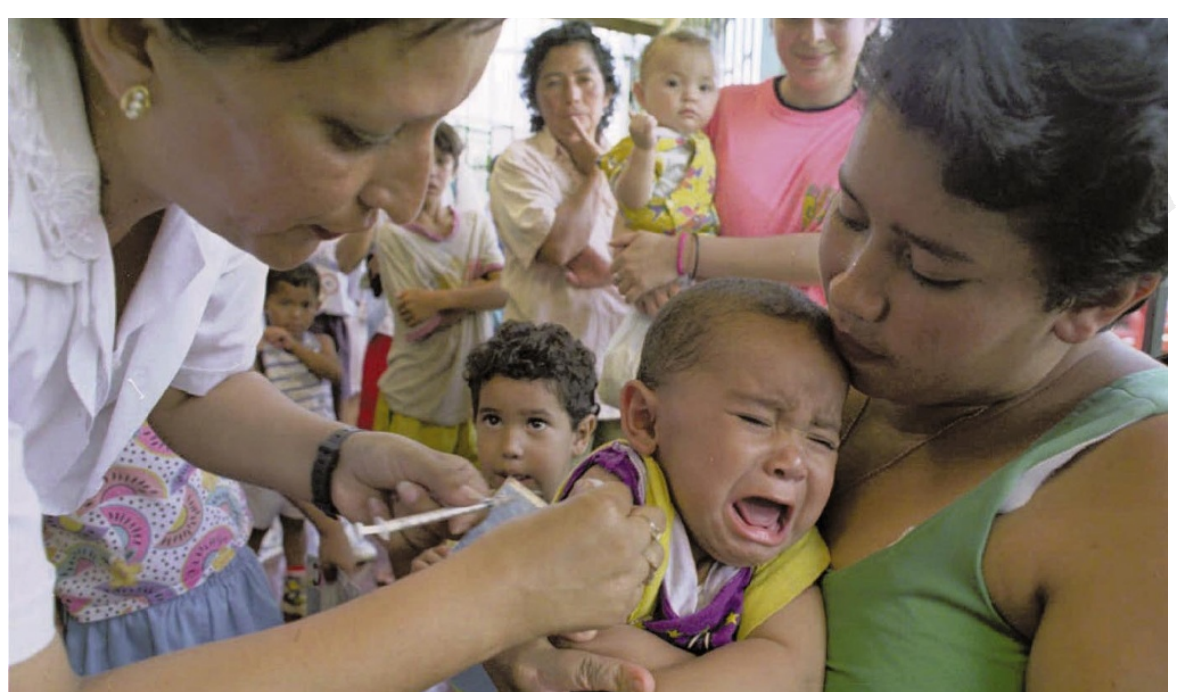

The Seoul institute is part of an international initiative to protect children against infectious diseases.

demiological and burden of disease studies, and on assessing demand for specific vaccines in Asia, as well as conducting vaccine clinical trials and field studies.

Of particular interest as a first target will be Haemophilus influenzae type b, a major cause of bacterial meningitis in young children that seems to be more widespread in Asia than previously thought, but for which no reliable epidemiological data are available to allow effective vaccine application.

After the building has been completed in 2000 and around 200 staff recruited, the institute plans to expand its role to include laboratory research on vaccine candidates, production processes and scaled-up research using a small pilot plant, as well as research into vaccine production quality and safety.

Funding for the first few years of operation is fairly secure. Construction costs for the institute, which could be as high as US $\$ 50$ million, will be covered by the Korean government, and of the estimated $\$ 3.9$ million operating budget for 1998, the government will provide \$1.5 million, UNDP \$1.0 million and private industry $\$ 0.8$ million, leaving only $\$ 0.6$ million to be raised.

But when the institute is at full-scale operation and requires an annual operating budget of about \$15-20 million, it is not clear where the money will come from. The Korean government has guaranteed to provide 30 per cent, but UNDP has not guaranteed the rest.

WHO officials on the board are still concerned that the institute could end up tapping into the \$30-million donor budget for the Children's Vaccine Initiative, and institute officials have had to tread warily in defining the institute's role so as not to appear to overlap with the initiative or other WHO activities in the region.

But Richard Mahoney, director of insti- tutional development at the institute's temporaryheadquarters in Seoul, argues that the institute is a "new resource that will attract new funds", as witnessed by the substantial contribution from the Korean government and the contributions from Western vaccine manufacturers.

There has been a change of attitude by private industry in recent years, says Roy Widdus, coordinator of the Children's Vaccine Initiative, and Western companies now see a viable market in certain sectors of the developing world and are more willing to work with nonprofit organizations.

\section{Critical}

But steady support in the form of donations from countries, in particular the United States and Japan, which have yet to clarify their position on the IVI, will be "critical" for the institute's future, says one board member.

The first meeting last week of a support council for the institute composed of representatives of the 28 signatory nations, prospective signatory countries, donor institutions and industry, attracted a large number of participants. This suggests there is broad support for the institute and countries may be willing to donate new money to it.

Another challenge facing the IVI is recruitment of a top-quality director to head it, a process initiated last week by the board. Seoul does not offer the cosmopolitan attractions of other Asian cities such as Hong Kong and Singapore (which were early candidates to host the institute). Nor is Seoul in a developing country where the director would be seen to be taking on a humanitarian mission. Nevertheless, one institute official says that high-quality individuals have already expressed interest in the post.

DavidSwinbanks 